\title{
АНАЛИТИЧЕСКОЕ СОПРОВОЖДЕНИЕ НАРАБОРКИ ОПЫТНО-ПРОМЫШЛЕННОЙ ПАРТИИ КАТАЛИЗАТОРА ГИДРООЧИСТКИ ДИЗЕЛЬНОГО ТОПЛИВА
}

Сайко А.В., Надеина К.А., Данилевич В.В., Климов О.В., Носков А.С. ФГБУН ФИЦ Институт катализа им. Г. К. Борескова СО РАН, Новосибирск, Россия saiko@catalysis.ru

DOI: 10.26902/ASFE-11_75

В настоящее время постоянно ужесточаются экологические и химмотологические требования к дизельным топливам. Производство топлив, удовлетворяющих нормам Евро-5 и Евро-6 возможно только при использовании катализаторов гидроочистки последнего поколения. В России при разработке импортозамещающих катализаторов в условиях исследовательских институтов, для контроля химических, текстурных, структурномеханических и каталитических свойств, научным сотрудникам доступны самые разнообразные информативные методы анализа. Когда процесс оптимизации катализатора завершен, встает вопрос о наработке опытно-промышленных партий на промышленном оборудовании. Разовая загрузка типичного реактора гидроочистки низкого давления составляет не менее 30 тонн катализатора. Т.е. необходимо масштабировать процесс синтеза от лабораторного (десятки граммов) до промышленного (десятки тонн) уровня.

Синтез катализатора гидроочистки - сложный процесс, состоящий из нескольких последовательных стадий. На первой из термоактивированного гидроксида алюминия получают псевдобемит с заданными текстурными характеристиками. Далее псевдобемит пептизируют и путем грануляции образовавшейся пасты получают носитель необходимой формы с заданными параметрами влагоемкости и прочности на раздавливание. Носитель пропитывают многокомпонентным раствором, содержащим металлы в определенных комплексных соединениях, а полученный катализатор сушат. Для получения качественного катализатора на каждой стадии необходимо контролировать до 10 различных характеристик полупродуктов. Таким образом, синтез опытно-промышленной партии катализатора - это серьезная задача не только с точки зрения соблюдения условий синтеза, но и объемная работа для аналитического контроля качества процесса приготовления катализатора. Особенно это актуально ввиду того, что на действующих российских катализаторных производствах нет готовой аналитической базы для характеризации катализаторов гидроочистки последнего поколения.

Так, например, для контроля содержания нанесенных активных компонентов катализатора, в исследовательских лабораториях, зачастую используют многоэлементный информативный метод ИСП-АЭС, который практически не присутствует в парке аналитического оборудования большинства катализаторных предприятий. Проблемой встает отсутствие методик анализа основного компонента на всех стадиях синтеза катализатора: анализ сырья, анализ пропиточных растворов, анализ сливных вод, анализ катализатора.

Для сопоставления результатов анализа ряда текстурных и структурно-механических методов, присутствующих на заводе, но по характеристикам отличных от используемых в исследовательском институте, необходимо получить матрицы результатов анализа образцов с различным значением характеристик и получить корреляции для оценки результатов, получаемых при наработке на производстве.

В рамках аналитического сопровождения наработки опытно-промышленной партии катализатора гидроочистки дизельного топлива, был разработан и адаптирован ряд методик анализа сырья, полупродуктов и продуктов, получены матрицы для корреляции получаемых результатов анализа и разработан график аналитического контроля производства катализатора, представленные в настоящей работе.

Работа выполнена в рамках государственного задания Института катализа СО РАН (проект АAAA-A21121011890074-4). 